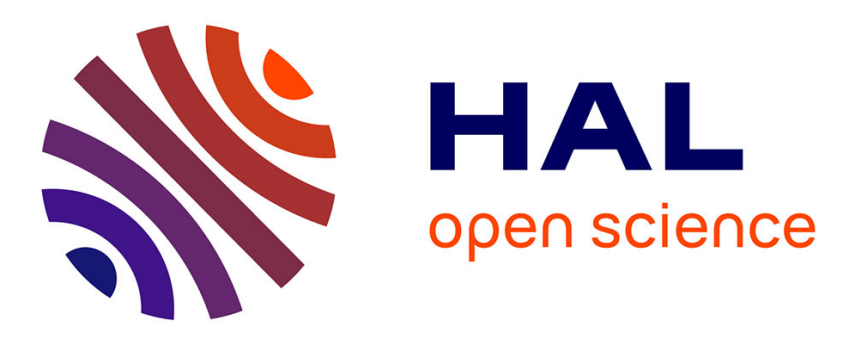

\title{
Delayed ileal perforation from sodium polystyrene sulfonate
}

\author{
Anne-Laure Faucon, Michel Daudon, Vincent Frochot, Dominique Bazin, \\ Benoit Terris, Valérie Caudwell
}

\section{To cite this version:}

Anne-Laure Faucon, Michel Daudon, Vincent Frochot, Dominique Bazin, Benoit Terris, et al.. Delayed ileal perforation from sodium polystyrene sulfonate. Kidney International, 2018, 93 (5), pp.1251-1252. 10.1016/j.kint.2017.10.014 . hal-01822679

\section{HAL Id: hal-01822679 https://hal.sorbonne-universite.fr/hal-01822679}

Submitted on 25 Jun 2018

HAL is a multi-disciplinary open access archive for the deposit and dissemination of scientific research documents, whether they are published or not. The documents may come from teaching and research institutions in France or abroad, or from public or private research centers.
L'archive ouverte pluridisciplinaire $\mathbf{H A L}$, est destinée au dépôt et à la diffusion de documents scientifiques de niveau recherche, publiés ou non, émanant des établissements d'enseignement et de recherche français ou étrangers, des laboratoires publics ou privés. 


\title{
Delayed ileal perforation from sodium polystyrene sulfonate
}

\author{
Anne-Laure Faucon ${ }^{1}$, Michel Daudon ${ }^{2,3,4}$, Vincent Frochot ${ }^{2,3,4}$, Dominique Bazin ${ }^{3,5,6}$, Benoît Terris ${ }^{7,8,9}$ and Valérie Caudwell ${ }^{1}$ \\ ${ }^{1}$ Department of Nephrology and Internal Medicine, Centre Hospitalier Sud Francilien, Corbeil, France; ${ }^{2}$ Department of Physiology, Hôpital \\ Tenon, APHP, Paris, France; ${ }^{3}$ Faculty of Medicine, Pierre et Marie Curie University, Paris, France; ${ }^{4}$ INSERM UMRS 1155, Paris, France; \\ ${ }^{5}$ Laboratoire de Physique des Solides, CNRS UMR 8502, Paris-Sud University, Orsay, France; ${ }^{6}$ Laboratoire de Chimie de la Matière Condensée \\ de Paris, Pierre et Marie Curie University, Collège de France, Paris, France; ' Department of Pathology, Hôpital Cochin, APHP, Paris, France; \\ ${ }^{8}$ Paris-Descartes University, Faculty of Medicine, Paris, France; and ${ }^{9}$ INSERM U1016-UMR 8104, Institut Cochin, Paris, France
}

Correspondence: Anne-Laure Faucon, Centre Hospitalier Sud Francilien, Service de Néphrologie-Médecine Interne, 116 Blvd Jean Jaurès, 91100 Corbeil-Essonnes, France. E-mail: anne-laure.faucon@aphp.fr
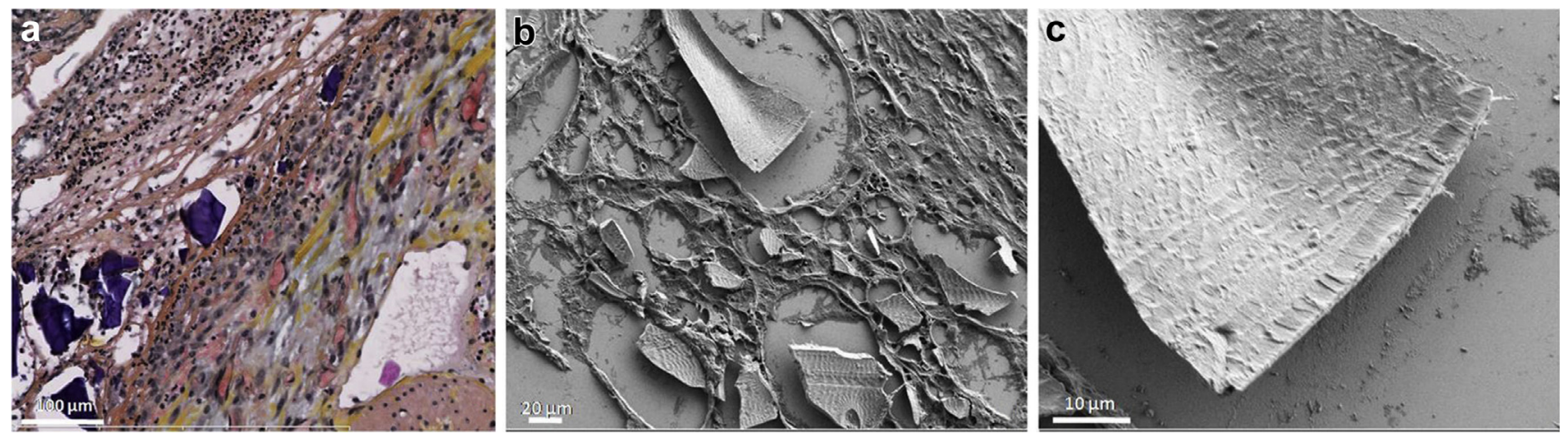

Figure 1 | Optical microscopy with hematoxylin and eosin staining revealed inflammatory lesions with basophilic and purple polygonal crystals in the ileal ulceration and at the serosal surface (a). Scanning electron microscopy of sorbitol-free sodium polystyrene sulfonate crystals $(\mathbf{b}, \mathbf{c})$. To optimize viewing of this image, please see the online version of this article at www.kidney-international.org.

A 66-year-old man, without a significant medical history, was admitted to the hospital for polyarthralgia. He reported hemorrhagic diarrhea and having been treated with amoxicillin and metronidazole a month prior to admission. Reactive arthritis was first suspected. His serum creatinine level was $0.759 \mathrm{mg} / \mathrm{dl}$. He received nonsteroidal anti-inflammatory drugs. After 3 days, he was admitted to our unit with acute kidney failure. His serum creatinine level was
$8.932 \mathrm{mg} / \mathrm{dl}$. Proteinase-3 anti-neutrophil cytoplasmic antibodies were strongly positive, and granulomatosis with polyangiitis was confirmed by kidney biopsy. Remission was obtained with plasma exchanges, corticosteroids, and i.v. cyclophosphamide. On day 12, he developed a pneumoperitoneum, and on laparotomy, a localized ileal perforation was noted. A partial ileal resection with ileostomy was performed. Gross examination showed a large ileal ulcer. Histologic analysis showed no
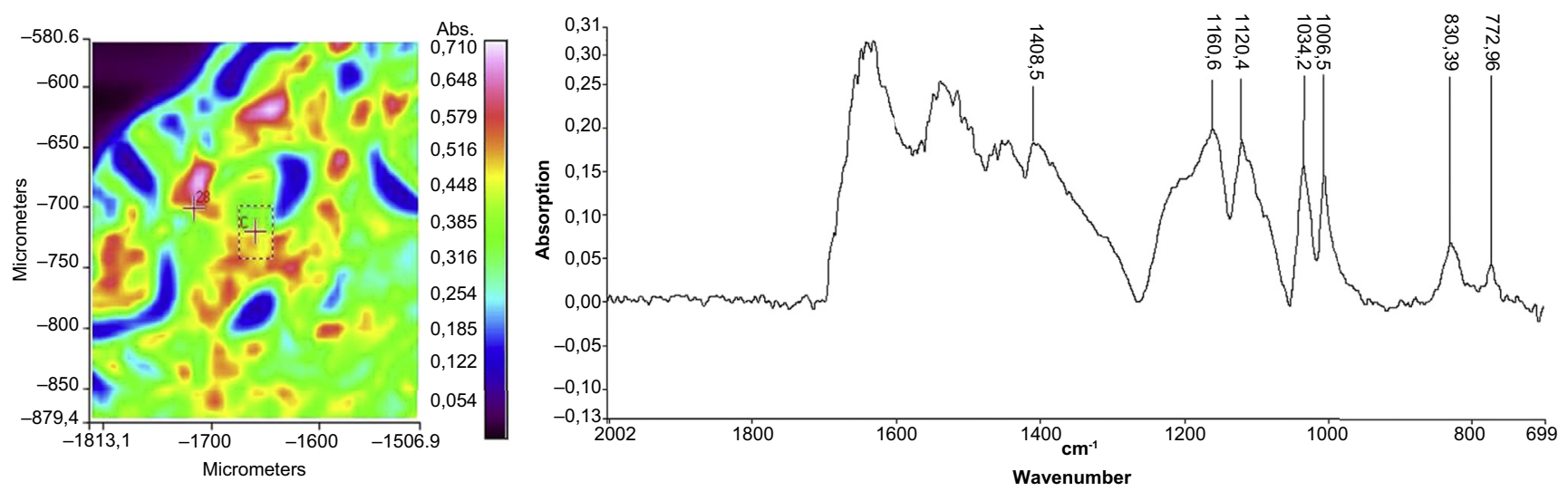

Figure 2 | Fourier-transform infrared spectroscopy map and spectrum of crystal deposited in ileal tissue, confirmed to be of sorbitol-free sodium polystyrene sulfonate crystal origin. 
sign of vasculitis, but inflammation, with basophilic and purple polygonal crystals in the digestive lumen, in the wall of the ulcer, and at the serosal surface, was noted (Figure 1a, b, and c). Drug-induced crystals were suspected, and a history of sorbitol-free sodium polystyrene sulfonate (SPS), taken orally 20 days before (total dose: $60 \mathrm{~g}$ ), was obtained. The diagnosis was confirmed using infrared spectroscopy (Figure 2).

SPS is a non-absorbable ion-exchange resin widely prescribed for the management of hyperkalemia. SPS-related gastrointestinal adverse events have been reported in isolated case reports, with an incidence of $0.27 \%-1.8 \%$. These events include diarrhea, bleeding, ischemic colitis, focal and deep ulceration, necrosis, and perforation. The risk factors include chronic kidney disease, hypotension, hypovolemia, immunosuppression, postoperative status, and obstructive bowel disease. The median time from the first SPS dose to the occurrence of symptoms is 2 days (interquartile range: $<1-5$ d). However, as in our patient, the diagnosis should be suspected, even if SPS has been stopped several days before the adverse event, especially in patients with additional risk factors.

\section{DISCLOSURE}

All the authors declared no competing interests.

\section{AUTHOR CONTRIBUTIONS}

All authors contributed to patient care. A-LF and VC wrote the article. $\mathrm{MD}, \mathrm{VF}, \mathrm{DB}$, and $\mathrm{BT}$ created the figures. All authors have read and approved the submission of the article. Written consent for publication was obtained. 